\title{
Article \\ Effect of Cutting Parameters and Tool Geometry on the Performance Analysis of One-Shot Drilling Process of AA2024-T3
}

\author{
Muhammad Aamir ${ }^{1} *(\mathbb{D})$, Khaled Giasin ${ }^{2}$ (D), Majid Tolouei-Rad ${ }^{1}$, Israr Ud Din ${ }^{3}$, Muhammad Imran Hanif ${ }^{4}$, \\ Ugur Kuklu $^{5}$, Danil Yurievich Pimenov ${ }^{6}$ and Muhammad Ikhlaq ${ }^{1}$
}

1 School of Engineering, Edith Cowan University, Joondalup 6027, Australia; m.rad@ecu.edu.au (M.T.-R.); mikhlaq@our.ecu.edu.au (M.I.)

2 School of Mechanical and Design Engineering, University of Portsmouth, Portsmouth PO1-3DJ, UK; khaled.giasin@port.ac.uk

3 Research Centre for Modelling and Simulation (RCMS), National University of Sciences and Technology (NUST), Sector H-12, Islamabad 44000, Pakistan; israr.rcms@rcms.nust.edu.pk

4 Department of Mechanical Engineering, CECOS University of Information Technology and Emerging Sciences, Peshawar 25000, Pakistan; imranhanif@cecos.edu.pk

5 Department of Mechanical Engineering, Faculty of Engineering, Karamanoglu Mehmetbey University, Karaman 70100, Turkey; ugurkoklu@kmu.edu.tr

6 Department of Automated Mechanical Engineering, South Ural State University, Lenin Prosp. 76, 454080 Chelyabinsk, Russia; danil_u@rambler.ru

* Correspondence: m.aamir@ecu.edu.au

Citation: Aamir, M.; Giasin, K.; Tolouei-Rad, M.; Ud Din, I.; Hanif, M.I.; Kuklu, U.; Pimenov, D.Y.; Ikhlaq, M. Effect of Cutting Parameters and Tool Geometry on the Performance Analysis of One-Shot Drilling Process of AA2024-T3. Metals 2021, 11, 854. https://doi.org/10.3390/met11060854

Academic Editor: Jorge Salguero

Received: 16 April 2021

Accepted: 20 May 2021

Published: 23 May 2021

Publisher's Note: MDPI stays neutral with regard to jurisdictional claims in published maps and institutional affiliations.

Copyright: (c) 2021 by the authors. Licensee MDPI, Basel, Switzerland. This article is an open access article distributed under the terms and conditions of the Creative Commons Attribution (CC BY) license (https:/ / creativecommons.org/licenses/by/ $4.0 /)$.

\begin{abstract}
Drilling is an important machining process in various manufacturing industries. Highquality holes are possible with the proper selection of tools and cutting parameters. This study investigates the effect of spindle speed, feed rate, and drill diameter on the generated thrust force, the formation of chips, post-machining tool condition, and hole quality. The hole surface defects and the top and bottom edge conditions were also investigated using scan electron microscopy. The drilling tests were carried out on AA2024-T3 alloy under a dry drilling environment using 6 and $10 \mathrm{~mm}$ uncoated carbide tools. Analysis of Variance was employed to further evaluate the influence of the input parameters on the analysed outputs. The results show that the thrust force was highly influenced by feed rate and drill size. The high spindle speed resulted in higher surface roughness, while the increase in the feed rate produced more burrs around the edges of the holes. Additionally, the burrs formed at the exit side of holes were larger than those formed at the entry side. The high drill size resulted in greater chip thickness and an increased built-up edge on the cutting tools.
\end{abstract}

Keywords: drilling; thrust force; hole quality; surface defects; chip formation; post-machining tool condition; AA2024-T3

\section{Introduction}

Aluminium alloys contribute to many manufacturing industries such as the aerospace and automotive industries, where strong, durable, and lightweight products are required [1]. Alloys of aluminium, particularly those from the 2000 series, are commonly used in modern aircrafts' airframe structures. For instance, AA2024-T3 is installed in aircraft fuselage skins due to its high fatigue resistance [2]. Furthermore, in the aerospace industry, the drilling process is used to assemble different structures, and thus a large number of holes are required for installing rivets and bolts [3-5]. Poor hole quality can lead to part rejections in quality control. Hence, a higher degree of research is required to enhance the holes' quality and minimise the incidence associated with the drilling operation [6,7].

Tool wear, chip formation, and hole quality are key parameters of the drilling process and are strongly influenced by spindle speed $(n)$, feed rate $(f)$, tool geometry, machine tool setup, and cutting conditions such as wet/dry or other environmental factors [8-12]. In 
contrast to wet machining, dry drilling is preferable to reduce the environmental impact of coolants and eliminate the costs of cutting fluids [13]. However, during the dry drilling process, there are more chances of forming a built-up edge (BUE), which can reduce the tool's life and affect the hole quality [14]. Hence, the proper selection of drilling parameters is essential in combination with the use of suitable drilling tools to avoid deformation of the workpiece or breakage of the cutting tool [15]. Previous studies for improving the drilling operation and producing high-quality holes are given in Table 1.

Table 1. Previous work on the effect of drilling parameters: Aluminium/other metals.

\begin{tabular}{|c|c|c|c|}
\hline Material & Cutting Parameters & Output Parameters & Ref. \\
\hline $\begin{array}{l}\text { Al6061, } \\
\text { Al6351, } \\
\text { Al7075 }\end{array}$ & $\begin{array}{c}n=90,200,250,400(\mathrm{rpm}) \\
f=0.15,0.2,0.3,0.36(\mathrm{~mm} / \mathrm{rev}) \\
\text { Point angle }=90^{\circ}, 118^{\circ} \\
\text { HSS drill bit } \\
D=10(\mathrm{~mm})\end{array}$ & $\begin{array}{l}\text { Hole size, } \\
\text { Thrust force }\end{array}$ & [16] \\
\hline Al6061 & $\begin{array}{c}n=1000,2000,3000(\mathrm{rpm}) \\
f=100,120,150(\mathrm{~mm} / \mathrm{min}) \\
D=6,8,10(\mathrm{~mm})\end{array}$ & $\begin{array}{l}\text { Thrust force, } \\
\text { Torque, } \\
\text { Circularity error }\end{array}$ & [17] \\
\hline Al7075 & $\begin{array}{c}V_{c}=40,80,120(\mathrm{~m} / \mathrm{min}) \\
f=0.05,0.1,0.15(\mathrm{~mm} / \mathrm{rev}) \\
\text { Point angle }=120^{\circ}, 130^{\circ}, 140^{\circ} \\
n=465,695,795(\mathrm{rpm})\end{array}$ & Thrust force & [18] \\
\hline Al7075 & $\begin{array}{c}f=18,20,26 \mathrm{~mm} / \mathrm{min} \\
\text { Clearance angle }=4^{\circ}, 6^{\circ}, 8^{\circ} \\
\text { Point angle }=100^{\circ}, 110^{\circ}, 118^{\circ} \\
\text { D }=8,10,12(\mathrm{~mm}) \\
\text { HSS drill bit }\end{array}$ & $\begin{array}{l}\text { Burr height, } \\
\text { Thrust force, } \\
\text { Surface roughness, } \\
\text { Circularity error }\end{array}$ & [19] \\
\hline Al7075 & $\begin{array}{c}V_{c}=50,100,150(\mathrm{~m} / \mathrm{min}) \\
f=0.15,0.2,0.25(\mathrm{~mm} / \mathrm{rev}) \\
D=8,10,12(\mathrm{~mm}) \\
\text { Carbide drill bit } \\
n=600,800,1000(\mathrm{rpm})\end{array}$ & $\begin{array}{l}\text { Thrust force, } \\
\text { Torque }\end{array}$ & [20] \\
\hline TI-6Al-4V & $\begin{array}{c}f=10,12,14(\mathrm{~mm} / \mathrm{min}) \\
\text { Helix angle }=25^{\circ}, 30^{\circ} \\
D=10 \mathrm{~mm} \\
\text { Carbide drill bit }\end{array}$ & $\begin{array}{l}\text { Surface roughness, flank wear, } \\
\text { and drill vibration }\end{array}$ & [21] \\
\hline $\begin{array}{l}\text { Ti-6Al-4V } \\
\text { Al7010 } \\
\text { Al2024. }\end{array}$ & $\begin{array}{c}V_{c}=10,20,30(\mathrm{~m} / \mathrm{min}) \\
f=0.07,0.14,0.21(\mathrm{~mm} / \mathrm{rev}) \\
D=6.35 \mathrm{~mm} \\
\text { Carbide twist drills }\end{array}$ & $\begin{array}{c}\text { Burr size, } \\
\text { Hole size and circularity }\end{array}$ & [22] \\
\hline
\end{tabular}

For instance, Reddy et al. [16] reported that $n$ was the most dominant factor that affected the hole diameter following the $f$ during drilling of Al6061, Al6351, and Al7075. In comparison, the impact of point angle on hole diameter was the lowest. Kushnoore et al. [17] conducted drilling experiments on Al6061 and concluded that an increase in drill diameter, $n$, and $f$ affected the thrust force, torque, and circularity error. Gunay et al. [18] have demonstrated that increasing $f$ led to an increased thrust force while increasing drill point angle resulted in a lower thrust force. Moreover, a low $f$ and high point angle were suggested for attaining minimum surface roughness in the drilling of Al7075. In another study by Sreenivasulu and Rao [19], it was revealed that during the drilling of Al7075, the most influential parameters on burr height, thrust force, surface roughness, and circularity were $f$, point angle, and clearance angles, as compared to $n$ and drill diameter. Kyratsis et al. [20] concluded that tool diameter and $f$ affected the thrust force and torque. In contrast, the impact of $n$ on both the thrust force and torque was considerably smaller during Al7075 drilling. Balaji et al. [21] worked on the drilling of Ti-6Al-4V and concluded that high frictional stresses and heat generation increased with the increase in $n$ and helix angle. While the surface roughness was more influenced by $n$ and $f$; however, the helix angle did 
not contribute more to the surface roughness. It was further found that surface roughness was affected by the drill vibration. The reasons for the increase in the tool wear were the high $n$ and $f$. Abdelhafeez et al. [22] conducted drilling experiments on Ti-6Al-4V, Al7010, and A12024. The study found that the exit burr size was statistically more affected by $f$ in all the materials, and no significant impact of cutting speed and $f$ was found on the circularity error and diameter oversize. Furthermore, Pena et al. [23] developed a thresholding algorithm based on internal signals from spindle torque to detect non-desired burr formation during the drilling operations of Al7075-T6. The algorithm was successfully developed with an accuracy above $92 \%$ and was expected to be used as an effective quality control in drilling operations.

The above studies indicate that most of the previous work was conducted either on other metal alloys or when the cutting parameters were different. Moreover, some studies lack investigations into hole quality and other output parameters in combination with the thrust force or torque. Additionally, keeping in view the higher importance of the drilling process for high-quality holes, this work investigates the effect of tool geometry in terms of drill size, spindle speed, and feed rate in the one-shot dry drilling process of AA2024-T3 using the uncoated carbide tools. Therefore, the performance of the drilling process was evaluated in terms of thrust force, chip analysis, and tool conditions to assess the surface roughness and burrs formation. Furthermore, the hole surface defects were investigated using scan electron microscopy.

\section{Materials and Methods}

The drilling process was performed on a vertical manual milling machine using spindle speeds of 1000, 2000, and $3000 \mathrm{rpm}$ and feed rates of $0.04,0.08$, and $0.14 \mathrm{~mm} / \mathrm{rev}$. All the experiments were conducted without the use of coolants because dry conditions are considered an eco-friendlier process [24,25]. The tools selected were uncoated carbide drill bits. Carbide twist drills are highly acknowledged for drilling aluminium alloys, especially AA2024-T3 [26], due to their enhanced hardness and toughness [27]. T3 is the temper designation for aluminium alloy, which means the alloy is solution treated, cold-worked, and naturally aged [1]. Table 2 shows the technical specifications for the drill bits used in this study.

Table 2. Details of drill bits.

\begin{tabular}{ccc}
\hline \multicolumn{2}{c}{ Specification/Description } \\
\hline Type & Twist drill & Twist drill \\
Material & Uncoated carbide & Uncoated carbide \\
Number of flutes & 02 & 02 \\
Point angle & $140^{\circ}$ & $140^{\circ}$ \\
Helix angle & $30^{\circ}$ & $30^{\circ}$ \\
Drill diameter & $6 \mathrm{~mm}$ & $10 \mathrm{~mm}$ \\
Overall length & $66 \mathrm{~mm}$ & $70 \mathrm{~mm}$ \\
\hline
\end{tabular}

All the drilling experiments were performed on AA2024-T3, which is the commonly used alloy in the aerospace industry $[1,28]$. The thickness of the workpiece material was $10 \mathrm{~mm}$, and the dimensions were $200 \times 150 \mathrm{~mm}^{2}$. A Kistler force dynamometer type 9257BA was used to measure force signals during the drilling operation. The dynamometer was fitted on the machine bed, and a support plate was mounted on its top for safety, which also acted as a fixture to avoid deflection/vibration during the drilling operation. The thrust force was measured using the Kistler's dynamometer. The quality of the holes was evaluated using a digital microscope, and the tool condition was examined using the optical microscope. The average surface roughness $(R a)$ of the holes was measured three times at four different locations of the hole edges at $90^{\circ}$ using the surface roughness tester TR200 (PCWI- precision instrumentation, Australia), and the average readings were considered for evaluation. The $R a$ values were taken as per the International Organization 
for Standardization (ISO) code: 4287 . The hole surface quality was examined using scanning electron microscopy (SEM). The samples were cut in half and examined under SEM using a Hitachi SU5000 Chiyoda, Japan, scanning electron microscope. Finally, the percentage contribution that each input parameter had on the output parameters was evaluated using ANOVA (Analysis of Variance).

\section{Results and Discussion}

\subsection{Thrust Force}

Figure 1 shows the thrust force $\left(F_{z}\right)$ generated signals of $6 \mathrm{~mm}$ and $10 \mathrm{~mm}$ drills for one of the drilled holes. The first region of the force signals shows the drill engagement where the tool penetrated the workpiece and $F_{z}$ began processing. With the drill bit's advancement, the $F_{z}$ gradually increased then reached a steady state while the drill was in full contact with the workpiece. The $F_{z}$ declined rapidly when approaching the bottom side of the workpiece and then reached zero when the drill bit completely exited the workpiece, indicating the end of the drilling process [29].

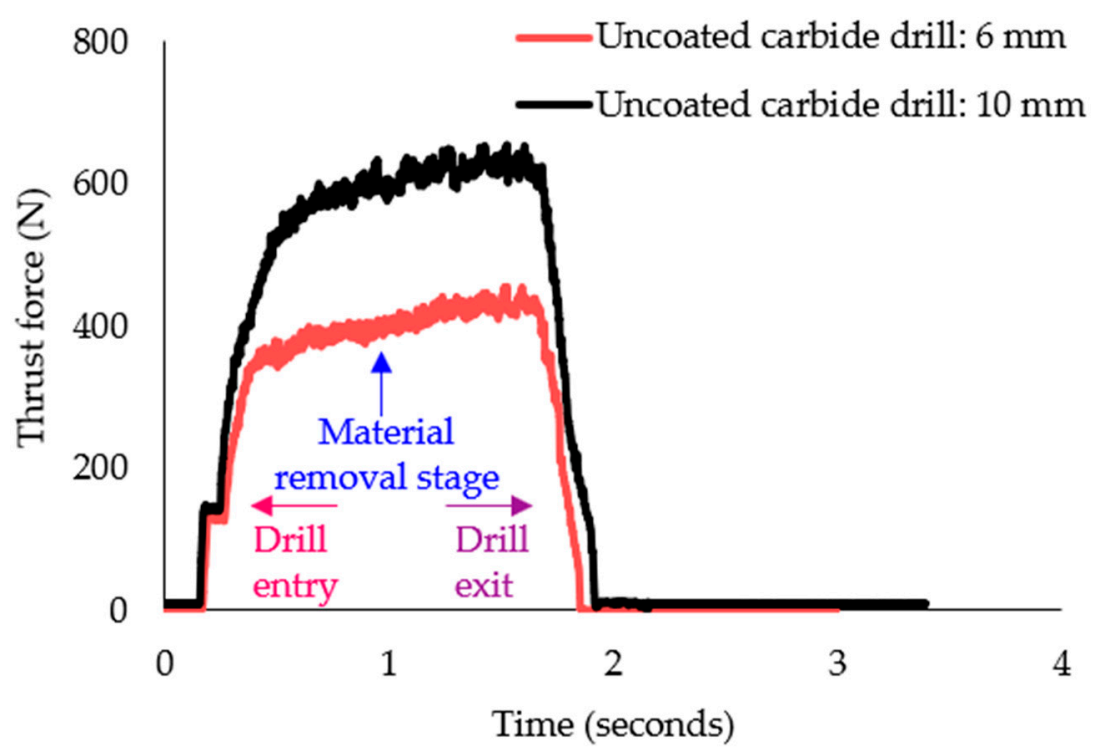

Figure 1. Profiles of average thrust force at $3000 \mathrm{rpm}$ and $0.14 \mathrm{~mm} / \mathrm{rev}$.

The average $F_{z}$ measured during the dry drilling process using $6 \mathrm{~mm}$ and $10 \mathrm{~mm}$ drill size at different $n$ and $f$ selected in this study is given in Figure 2. The results showed that the $10 \mathrm{~mm}$ drills generated a higher $F_{z}$ compared to that from the $6 \mathrm{~mm}$ drills due to the larger contact area between the drill and the workpiece. Figure 2 also illustrates that $F_{z}$ increased as $n$ and $f$ increased; however, the ANOVA analysis in Table 3 indicated that $f$ had the highest percentage contribution at $67.33 \%$, followed by the drill diameter with a contribution of $29.53 \%$, while the influence of $n$ was insignificant $(0.81 \%)$. The increase in $F_{z}$ due to the increase in $f$ might be associated with the increase in uncut chip thickness [30-32]. A confidence interval of $95 \%$ was used in the ANOVA; therefore, the influence of each process parameter on the responses was considered insignificant if their $p$-values were estimated at more than 0.05 . 


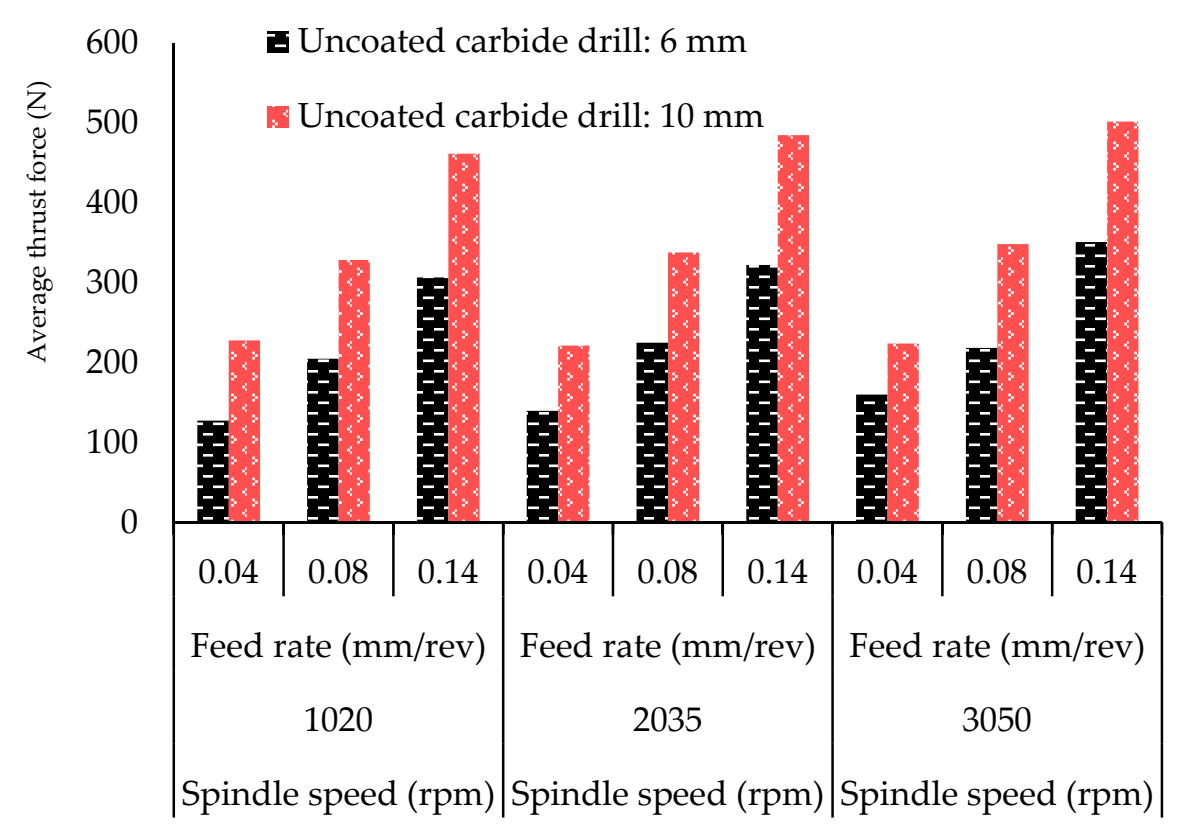

Figure 2. Average thrust force.

Table 3. ANOVA for thrust force.

\begin{tabular}{|c|c|c|c|c|c|c|c|}
\hline Source & DF & Seq SS & Contribution & Adj SS & Adj MS & F-Value & $p$-Value \\
\hline Model & 13 & 219,473 & $99.85 \%$ & 219,473 & $16,882.5$ & 199.83 & 0 \\
\hline$n$ & 2 & 1791 & $0.81 \%$ & 1791 & 895.5 & 10.6 & 0.025 \\
\hline$f$ & 2 & 147,992 & $67.33 \%$ & 147,992 & $73,995.8$ & 875.84 & 0 \\
\hline$D$ & 1 & 64,908 & $29.53 \%$ & 64,908 & 64,908 & 768.27 & 0 \\
\hline $\begin{array}{c}\text { 2-Way } \\
\text { Interactions }\end{array}$ & 8 & 4782 & $2.18 \%$ & 4782 & 597.8 & 7.08 & 0.038 \\
\hline$n \times f$ & 4 & 566 & $0.26 \%$ & 566 & 141.6 & 1.68 & 0.315 \\
\hline$n \times D$ & 2 & 103 & $0.05 \%$ & 103 & 51.3 & 0.61 & 0.588 \\
\hline$f \times D$ & 2 & 4113 & $1.87 \%$ & 4113 & 2056.6 & 24.34 & 0.006 \\
\hline Error & 4 & 338 & $0.15 \%$ & 338 & 84.5 & - & - \\
\hline Total & 17 & 219,811 & $100.00 \%$ & - & - & - & - \\
\hline
\end{tabular}

\subsection{Surface Roughness, Burr Formation, and Hole Surface Damage Analysis}

Figure 3 depicts the surface roughness $(R a)$ of holes drilled in AA2024-T3 alloy. The results show that increases in both $n$ and $f$ increased $R a$, irrespective of the drill size. However, $R a$ of the holes drilled using the $10 \mathrm{~mm}$ drill bits were found to be almost similar to those obtained from drill bits with a $6 \mathrm{~mm}$ size, which is in agreement with the findings of Köklü [33]. The minor increase from the large-size drills was speculated to be due to covering a larger contact area, resulting in increased BUE formation, which in turn increased the $F_{z}$ and $R a$ [34]. The high $R a$ due to the increase in $n$ is attributed to the rise in cutting temperature, which increases the thermal softening of the material and hole deformation [15]. Moreover, the high $f$ increased the thickness of the chips, which contributed to the higher values of $R a$ [30]. Table 4 from the ANOVA results shows that $n$ had the highest percentage contribution at $65.29 \%$, followed by $f$ with an impact of $32.72 \%$ on $R a$. The influence of $D$ and other interactions were found insignificant as their $p$-values were more than 0.05 . 


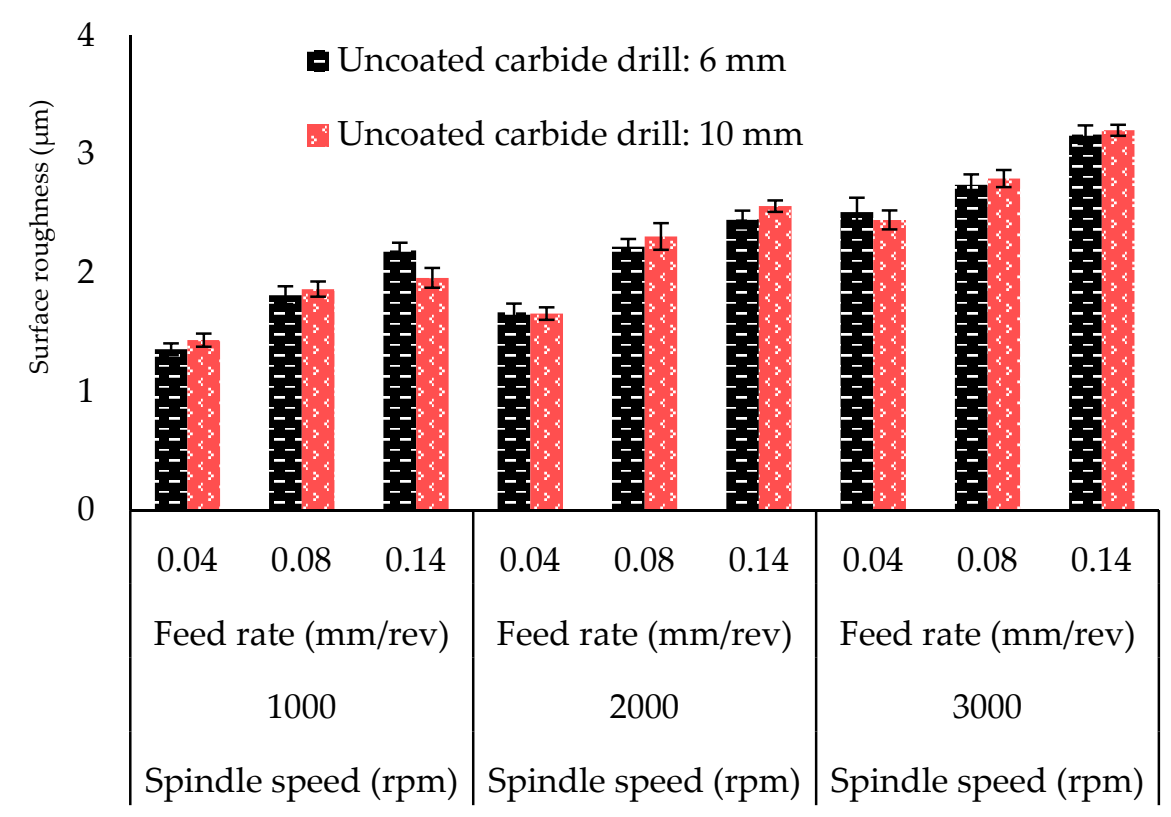

Figure 3. Average surface roughness.

Table 4. ANOVA for surface roughness.

\begin{tabular}{cccccccc}
\hline Source & DF & Seq SS & Contribution & Adj SS & Adj MS & F-Value & $p$-Value \\
\hline Model & 13 & 5.09143 & $99.39 \%$ & 5.09143 & 0.39165 & 50.3 & 0.001 \\
$n$ & 2 & 3.34469 & $65.29 \%$ & 3.34469 & 1.67235 & 214.8 & 0 \\
$f$ & 2 & 1.67586 & $32.72 \%$ & 1.67586 & 0.83793 & 107.63 & 0 \\
$D$ & 1 & 0.00061 & $0.01 \%$ & 0.00061 & 0.00061 & 0.08 & 0.793 \\
2-Way & & 0.07026 & $1.37 \%$ & 0.07026 & 0.00878 & 1.13 & 0.486 \\
Interactions & 8 & & & & & \\
$n \times f$ & 4 & 0.05686 & $1.11 \%$ & 0.05686 & 0.01421 & 1.83 & 0.287 \\
$n \times D$ & 2 & 0.00704 & $0.14 \%$ & 0.00704 & 0.00352 & 0.45 & 0.665 \\
$f \times D$ & 2 & 0.00637 & $0.12 \%$ & 0.00637 & 0.00319 & 0.41 & 0.689 \\
Error & 4 & 0.03114 & $0.61 \%$ & 0.03114 & 0.00779 & - & - \\
Total & 17 & 5.12257 & $100.00 \%$ & - & - & - & - \\
\hline
\end{tabular}

$n=$ Spindle speed,$f=$ Feed rate, $D=$ Diameter.

Another essential characteristic of hole quality was the burrs at the entry and exit of holes. Therefore, in this study, burrs around the hole edges were also thoroughly analysed using a digital microscope. The microscopic inspection also revealed less formation of burrs at the entry than those formed at the exit side. Additionally, both $n$ and $f$ contributed to the formation of burrs around the hole edges; however, $f$ was dominant over $n$ in increasing the burrs due to the high insertion of the drill because of the unstable performance [35]. The reason for high burr formation due to the higher $n$ was due to the high percentage of the elongation of the AA2024-T3 alloy [29]. Figure 4 also indicates that the drill diameter had a minor influence on burr size and height when drilling the AA2024-T3 alloy. However, it was challenging to evaluate burr formation using optical microscopy accurately; therefore, SEM images were used to further investigate the burr formation.

Figure 5 shows the borehole for 6 and $10 \mathrm{~mm}$ holes drilled using the same cutting parameters. The SEM graphs reveal that the hole edge quality at the entrance was better than at the exit, regardless of the drill size. Moreover, it was also found that the hole edge quality at the entrance was better in holes drilled using $6 \mathrm{~mm}$ drills than those drilled using the $10 \mathrm{~mm}$ drills. This was also observed in the remaining drilled holes using different cutting parameters. The larger contact area between the cutting tool and workpiece at the start of the drilling process means that larger thrust force is required before the cutting tool 
is in full contact with the workpiece, leading to increased deformations and damage to the hole entry.
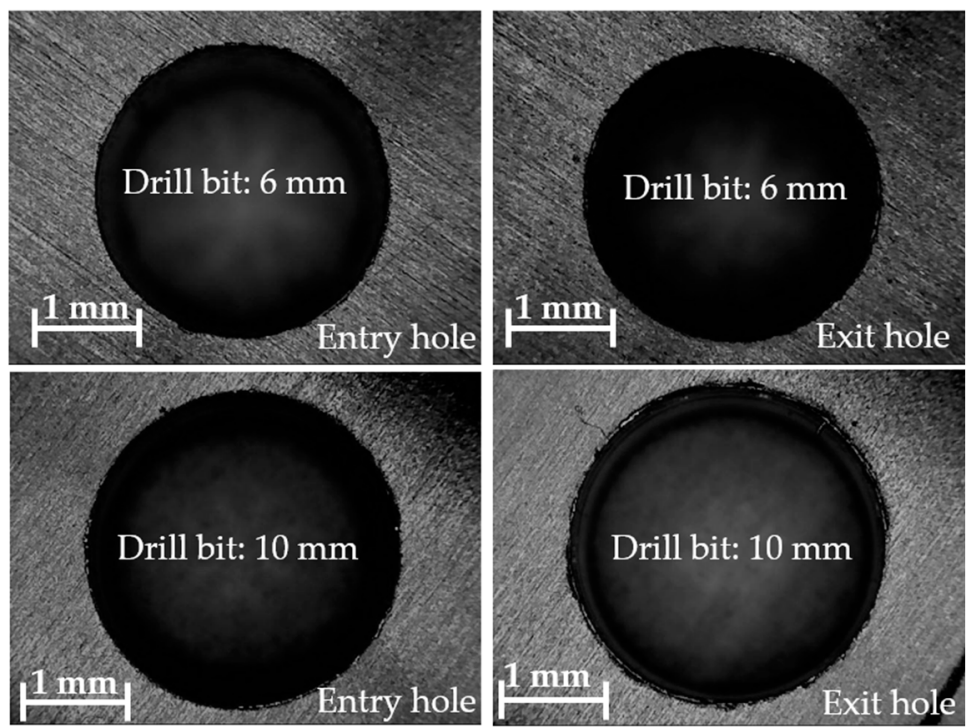

Figure 4. Quality of holes in terms of burrs at $3000 \mathrm{rpm}$ and $0.14 \mathrm{~mm} / \mathrm{rev}$.

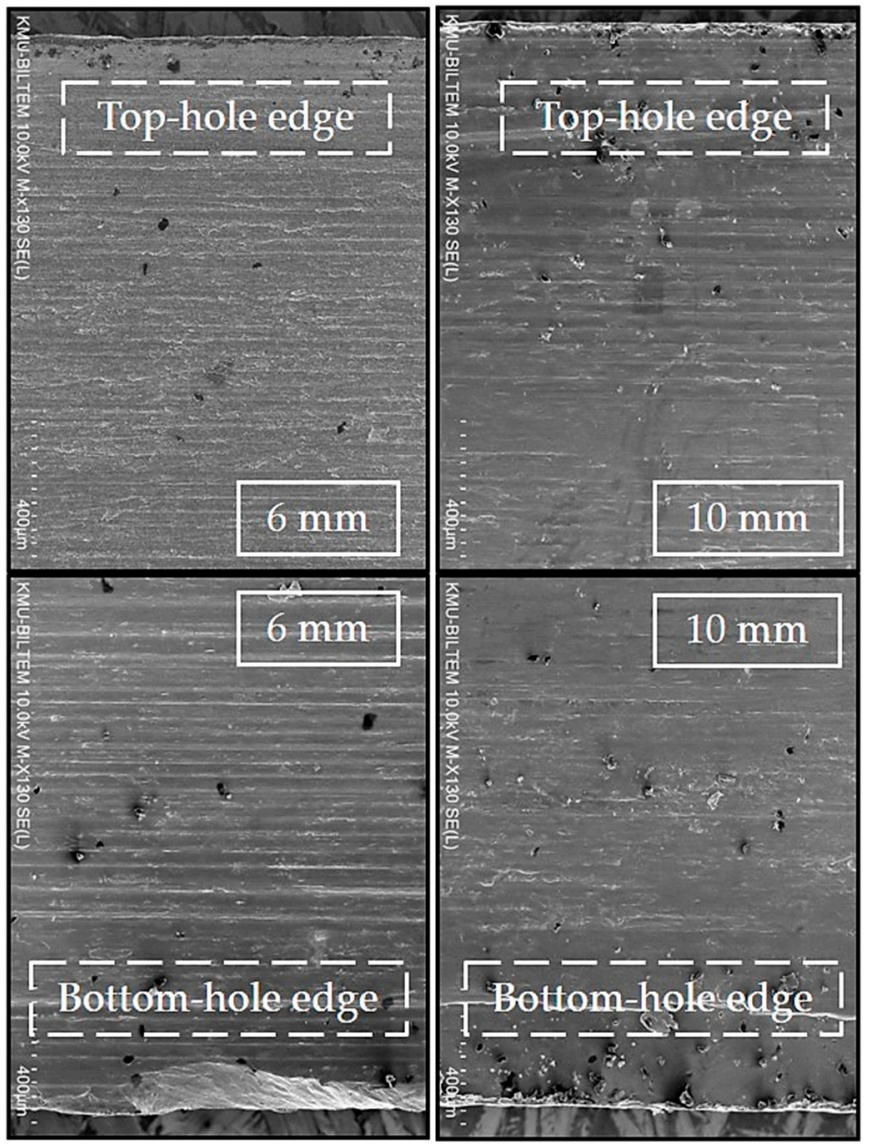

Figure 5. Borehole condition under SEM at $1000 \mathrm{rpm}$ and $0.04 \mathrm{~mm} / \mathrm{rev}$.

Similarly, the hole edge quality at the exit was better in holes drilled using $10 \mathrm{~mm}$ drills, as can be seen from Figure 5. It is speculated that the larger cross-sectional area of the $10 \mathrm{~mm}$ drills provided more stability and rigidity while drilling throughout the hole, which gave better cutting quality while the tool was exiting the workpiece. This claim 
can be supported by the fact that the surface deformations and damage observed on the boreholes drilled using $6 \mathrm{~mm}$ drills were somewhat more visible than those drilled using the $10 \mathrm{~mm}$ drills. Another observation supporting this claim is that aggressive helical feed marks were found on the inner surfaces of some of the holes drilled using the $6 \mathrm{~mm}$ drills, as shown in Figure 6. This would imply that the chip collision with the inner walls of the holes was more aggressive when using the $6 \mathrm{~mm}$ drills, which could be, as stated earlier, due to less drill stability.

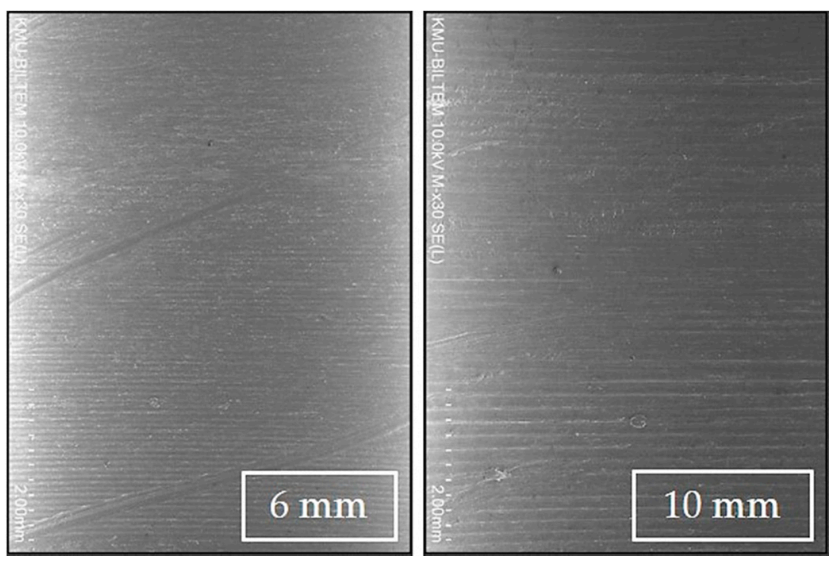

Figure 6. Borehole condition under SEM at $2000 \mathrm{rpm}$ and $0.08 \mathrm{~mm} / \mathrm{rev}$.

Figure 7 shows the surface condition of holes drilled using $6 \mathrm{~mm}$ drills at different feed rates. It was observed that increasing $f$ tended to reduce the hole surface quality. This is mainly attributed to the increased chip thickness with the increase in $f$. For example, when drilling at an $f$ of $0.14 \mathrm{~mm} / \mathrm{rev}$, there are more clear signs of smearing and plastic flow due to severe plastic deformation on the upper and lower sides of the hole as well as throughout its thickness. This was also observed in holes drilled using the $10 \mathrm{~mm}$ drills and therefore is purely related to the increase in $f$.
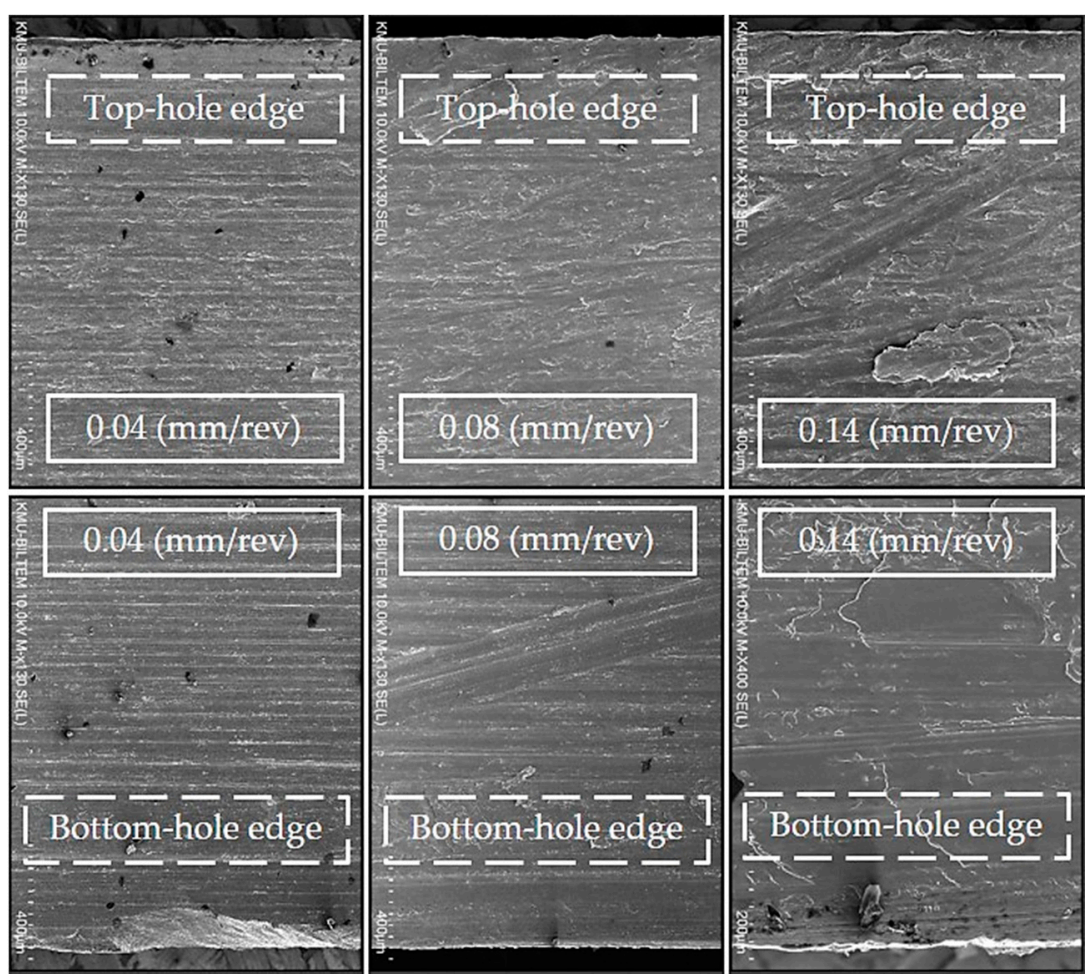

Figure 7. Borehole condition under SEM for holes drilled using $6 \mathrm{~mm}$ drills and $1000 \mathrm{rpm}$. 
Figure 8 shows the borehole condition for holes drilled using $10 \mathrm{~mm}$ drills at a different $n$ and a constant $f$ of $0.14 \mathrm{~mm} / \mathrm{rev}$. The results show that the edge quality at the hole entry seems to worsen with the increase in $n$, while the hole edge quality at the exit seemed to be unaffected. The results also showed that increasing $n$ beyond $2000 \mathrm{rpm}$ increased the severity of deformations due to plastic flow around the hole surface. This could be attributed to the increase in the cutting temperatures and ductility with the increase in $n$, which softens the material and induces more thermal stresses. It is also well known that the AA2024-T3 alloy possesses a relatively high percentage of elongation, which can affect the burr formation at the hole entry and exit sides [29]. For clarification, Figure 9 reveals the defects in the hole walls of AA2024-T3 from $6 \mathrm{~mm}$ and $10 \mathrm{~mm}$ drill bits.

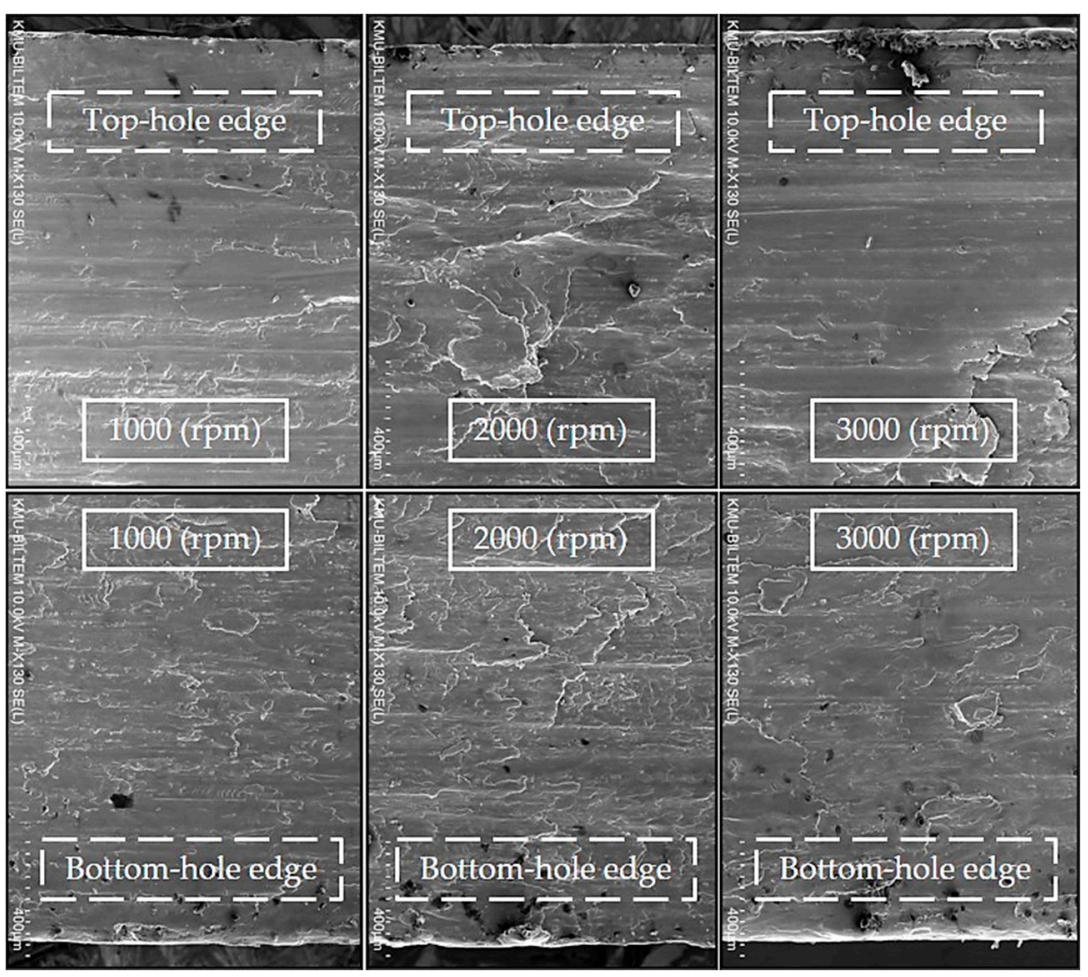

Figure 8. Borehole condition under SEM for holes drilled using $10 \mathrm{~mm}$ drills and $0.14 \mathrm{~mm} / \mathrm{rev}$.
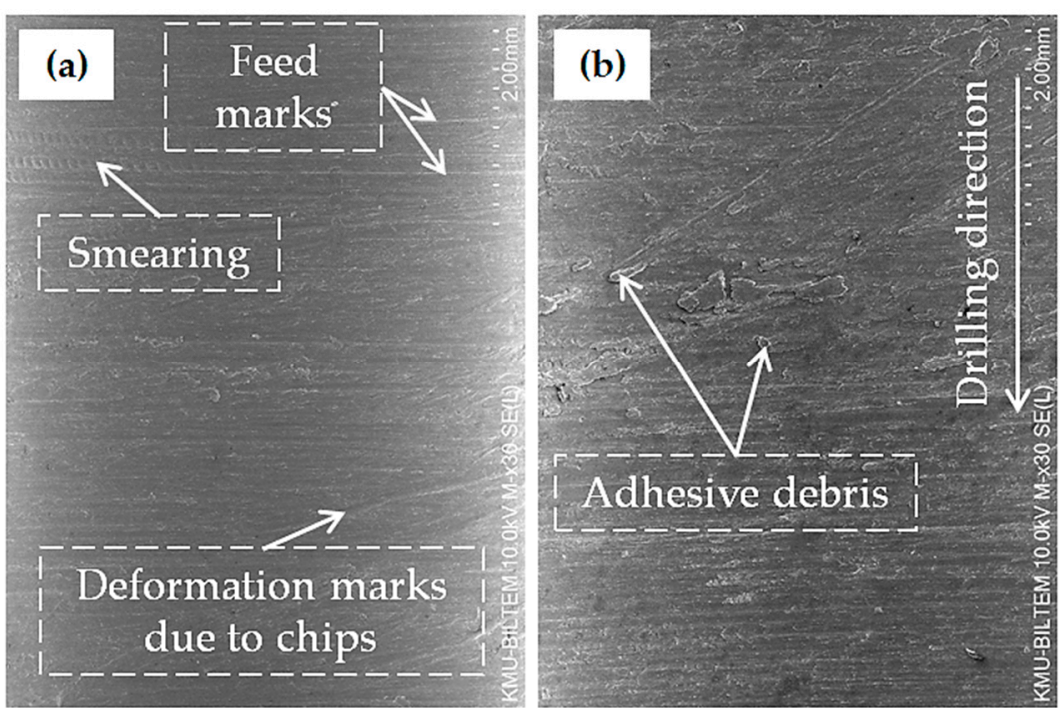

Figure 9. Hole surface damage analysis of AA2024-T3: (a) $6 \mathrm{~mm}$ drill bit and (b) $10 \mathrm{~mm}$ drill bit. 


\subsection{Chip Analysis and Tool Condition}

Chip formation and its breaking mechanism signify the smooth drilling process [36]. Accordingly, the long and continuous chips can easily become tangled around the drill bit flutes and require manual removal, affecting the production [37]. Furthermore, the undesirable chips increase the formation of built-up edge (BUE), which in return would reduce the quality of holes [38]. Commonly, the reason behind the formation of BUE is the higher value of the coefficient of friction at the tool-chip interface [39]. Figure 10 shows the chips produced during dry drilling of AA2024-T3 using 6 and $10 \mathrm{~mm}$ uncoated carbide drills. The chip analysis showed that $10 \mathrm{~mm}$ uncoated carbide drill bits had thickened chips compared to the drill size of $6 \mathrm{~mm}$ because of the large cross-sectional area covered by its larger size [40]. Figure 10 also shows that, with the increase in both $n$ and $f$, the length of the chip became shorter, while the thickness of the chip increased with the increase in $f$ and decreased with the increase in $n$, irrespective of the drill size.

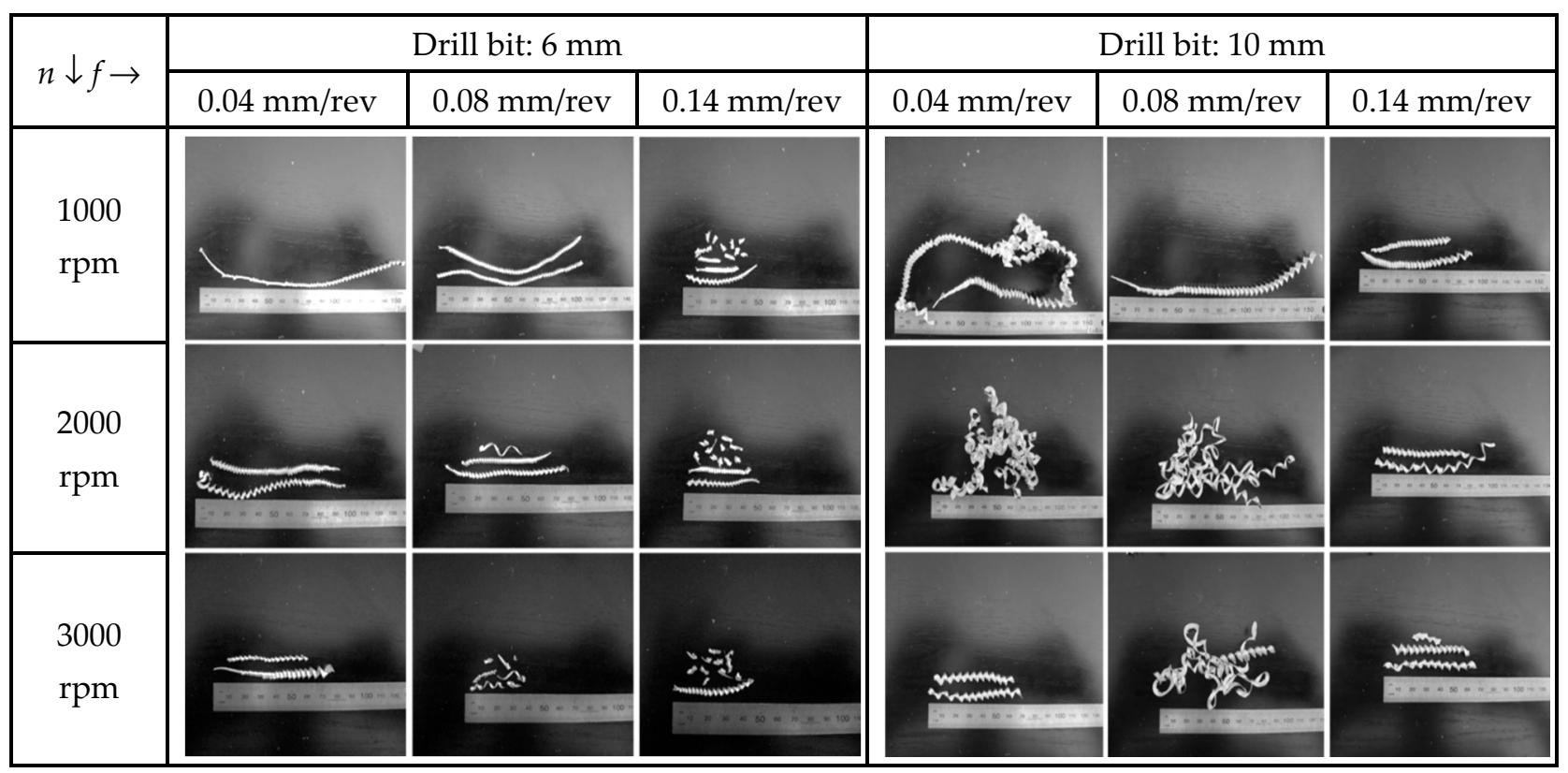

Figure 10. Analysis of chips.

In the machining process, chips can adhere to the cutting tool to form BUE, resulting in deterioration of the cutting tool [41]. Additionally, according to Rodríguez et al. [24], during dry drilling operations there are chances of both high friction phenomena and chemical diffusion, which cause adhesion, burn marks, and flank wear. Therefore, the higher formation of BUE in drilling affects the hole quality. Depending upon the materials of the cutting tools and different geometries, BUE formation varies under the same cutting conditions. Figure 11 shows the condition of $6 \mathrm{~mm}$ and $10 \mathrm{~mm}$ drill bits during the drilling process of AA2024-T3, which indicated a BUE on both the tools. The microscopic inspection showed a higher BUE on the $10 \mathrm{~mm}$ drill bit compared to the drill size of $6 \mathrm{~mm}$. The greater BUE on the $10 \mathrm{~mm}$ drill bit was due to larger chip formation, increased cutting forces, and the contact area between the cutting tool and the workpiece material. In contrast, small drill size led to easy chip evacuation and chip breakage due to the smaller chips. 

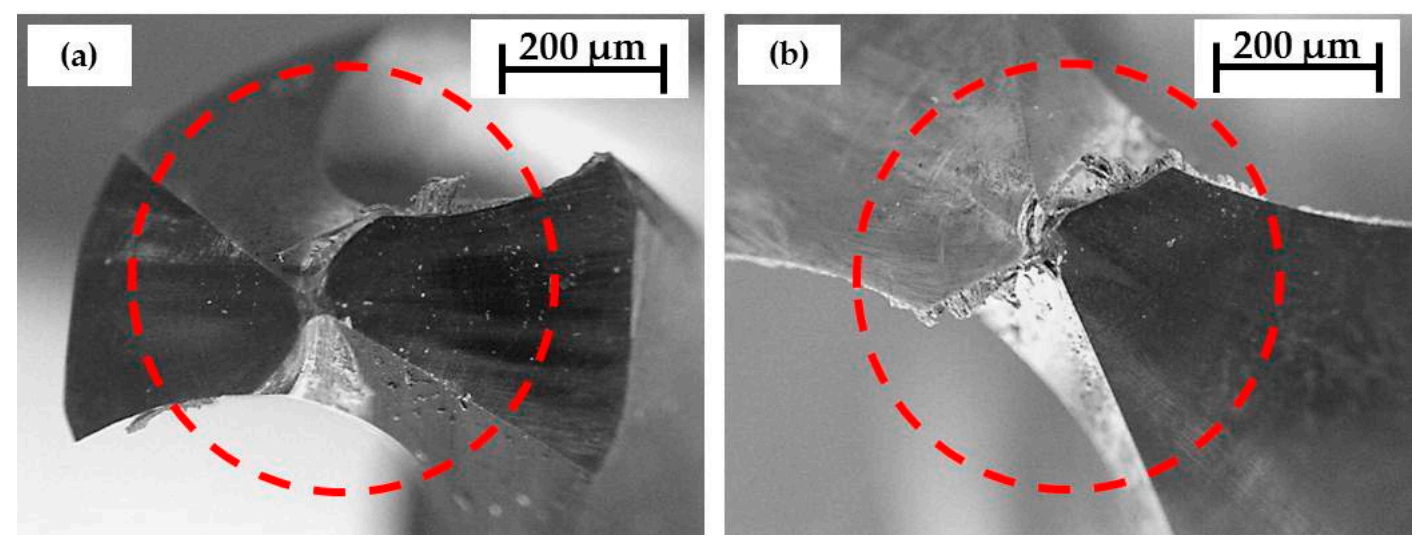

Figure 11. Post-machining tool conditions: (a) $6 \mathrm{~mm}$ drill bit and (b) $10 \mathrm{~mm}$ drill bit.

\section{Conclusions}

This study investigated the effect of tool geometry and cutting conditions, such as spindle speed and feed rate, for the improvement of holes drilled in AA2024-T3. The following conclusions could be made from the investigations:

- The thrust force was affected more with the increase in feed rate, while the impact of spindle speed on thrust force was found insignificant. Therefore, the percentage contributions of feed rate, drill size, and spindle speed on thrust force were $67.33 \%$, $29.53 \%$, and $0.81 \%$, respectively.

- The surface roughness increased with the increase in spindle speed and feed rate. The spindle speed had an impact of $65.29 \%$, following the feed rate which had a percentage contribution of $32.72 \%$, while the drill size had insignificant influence with a contribution of only $0.01 \%$.

- Both spindle speed and feed rate were influential on burrs formation; however, more burrs were formed with an increased feed rate. Furthermore, it was revealed that entry holes had fewer burrs than holes formed at the exit side.

- The $10 \mathrm{~mm}$ size tool covered a large cutting area and produced chips with high thickness, thus generating high thrust force compared to the $6 \mathrm{~mm}$ size tool. The high chip thickness resulted in high built-up edges on the drill bits because the small drill size enabled easy chip evacuation and breaking due to the short chip size. The large built-up edge should be avoided for high-quality holes.

- Both the drill sizes resulted in feed marks, chip debris, deformation due to chip adhesion, and smearing on the hole walls of AA2024-T3.

- The study could be further extended to assess other important hole metrics such as deviation of the hole from nominal size, circularity, cylindricity, and perpendicularity. Moreover, drill bits with coatings and other geometric parameters should be used for further improvement of the holes.

Author Contributions: Conceptualization, M.A. and M.T.-R.; methodology, M.A. and K.G.; validation, M.A., K.G., M.T.-R. and D.Y.P.; investigation, M.A., and U.K.; writing-original draft preparation, M.A., M.I.H., M.I. and I.U.D.; writing—review and editing, K.G., I.U.D., M.I., U.K., D.Y.P. and M.I.H. All authors have read and agreed to the published version of the manuscript.

Funding: This research received no external funding.

Institutional Review Board Statement: Not applicable.

Informed Consent Statement: Not applicable.

Data Availability Statement: The data presented in this study are available on request.

Conflicts of Interest: The authors declare no conflict of interest. 


$\begin{array}{ll}\text { Nomenclature } \\ \text { ANOVA } & \text { Analysis of Variance } \\ \text { BUE } & \text { Built-up edge } \\ \text { SEM } & \text { Scan electron microscope } \\ D & \text { Drill diameter } \\ f & \text { Feed rate } \\ n & \text { Spindle speed } \\ R_{a} & \text { Surface roughness } \\ F_{z} & \text { Thrust force } \\ V_{c} & \text { Cutting speed }\end{array}$

\section{References}

1. Aamir, M.; Giasin, K.; Tolouei-Rad, M.; Vafadar, A. A review: Drilling performance and hole quality of aluminium alloys for aerospace applications. J. Mater. Res. Technol. 2020, 9, 12484-12500. [CrossRef]

2. Dursun, T.; Soutis, C. Recent developments in advanced aircraft aluminium alloys. Mater. Des. 2014, 56, 862-871. [CrossRef]

3. Aamir, M.; Tolouei-Rad, M.; Giasin, K.; Nosrati, A. Recent advances in drilling of carbon fiber-reinforced polymers for aerospace applications: A review. Int. J. Adv. Manuf. Technol. 2019, 105, 2289-2308. [CrossRef]

4. Tolouei-Rad, M.; Aamir, M. Analysis of the Performance of Drilling Operations for Improving Productivity. In Drilling; ToloueiRad, M., Ed.; IntechOpen: London, UK, 2021; Available online: https://www.intechopen.com/online-first/analysis-of-theperformance-of-drilling-operations-for-improving-productivity (accessed on 16 April 2021).

5. Olvera, D.; de Lacalle, L.N.L.; Urbikain, G.; Lamikiz, A.; Rodal, P.; Zamakona, I. Hole making using ball helical milling on titanium alloys. Mach. Sci. Technol. 2012, 16, 173-188. [CrossRef]

6. Al-Tameemi, H.A.; Al-Dulaimi, T.; Awe, M.O.; Sharma, S.; Pimenov, D.Y.; Koklu, U.; Giasin, K. Evaluation of Cutting-Tool Coating on the Surface Roughness and Hole Dimensional Tolerances during Drilling of Al6061-T651 Alloy. Materials 2021, 14, 1783. [CrossRef] [PubMed]

7. Aamir, M.; Tolouei-Rad, M.; Giasin, K.; Vafadar, A.; Koklu, U.; Keeble, W. Evaluation of the Surface Defects and Dimensional Tolerances in Multi-Hole Drilling of AA5083, AA6061, and AA2024. Appl. Sci. 2021, 11, 4285. [CrossRef]

8. Zhao, H. Predictive Models for Forces, Power and Hole Oversize in Drilling Operations. Doctoral Dissertation, The University of Melbourne, Victoria, Australia, 1994.

9. Aamir, M.; Tu, S.; Tolouei-Rad, M.; Giasin, K.; Vafadar, A. Optimization and modeling of process parameters in multi-hole simultaneous drilling using taguchi method and fuzzy logic approach. Materials 2020, 13, 680. [CrossRef] [PubMed]

10. Aamir, M.; Tu, S.; Giasin, K.; Tolouei-Rad, M. Multi-hole simultaneous drilling of aluminium alloy: A preliminary study and evaluation against one-shot drilling process. J. Mater. Res. Technol. 2020, 9, 3994-4006. [CrossRef]

11. Aamir, M.; Tolouei-Rad, M.; Giasin, K.; Vafadar, A. Machinability of Al2024, Al6061, and Al5083 alloys using multi-hole simultaneous drilling approach. J. Mater. Res. Technol. 2020, 9, 10991-11002. [CrossRef]

12. Aamir, M.; Tolouei-Rad, M.; Vafadar, A.; Raja, M.N.A.; Giasin, K. Performance Analysis of Multi-Spindle Drilling of Al2024 with TiN and TiCN Coated Drills Using Experimental and Artificial Neural Networks Technique. Appl. Sci. 2020, 10, 8633. [CrossRef]

13. Sarikaya, M.; Gupta, M.K.; Tomaz, I.; Danish, M.; Mia, M.; Rubaiee, S.; Jamil, M.; Pimenov, D.Y.; Khanna, N. Cooling techniques to improve the machinability and sustainability of light-weight alloys: A state-of-the-art review. J. Manuf. Process. 2021, 62, 179-201. [CrossRef]

14. Bhowmick, S.; Alpas, A.T. Minimum quantity lubrication drilling of aluminium-silicon alloys in water using diamond-like carbon coated drills. Int. J. Mach. Tools Manuf. 2008, 48, 1429-1443. [CrossRef]

15. Osman, M.; Tamin, N.; Ahmad, M.; Rahman, M.A.; Wahid, M.; Maidin, N.; Bakar, M.A.; Azahar, A. Effect of cutting parameters on surface roughness in dry drilling of AISI D2 tool steel by using Taguchi method. J. Adv. Manuf. Technol. 2018, 12, 535-546.

16. Reddy, A.S.; Kumar, G.V.; Thirupathaiah, C. Influence of the cutting parameters on the hole diameter accuracy and the thrust force in drilling of aluminium alloys. Int. J. Innov. Res. Sci. Eng. Technol. 2013, 2, 6442-6450.

17. Kushnoore, S.; Noel, D.; Kamitkar, N.; Satishkumar, M. Experimental investigations on thrust, torque and circularity error in drilling of aluminium alloy (Al6061). Am. J. Mech. Ind. Eng. 2016, 1, 96-102.

18. Gunay, M.; Yasar, N.; Korkmaz, M.E. Optimization of Drilling Parameters for Thrust Force in Drilling of AA7075 Alloy. In Proceedings of the International Conference on Engineering and Natural Sciences, Sarajevo, Bosnia and Herzegovina, 24-28 May 2016.

19. Sreenivasulu, R.; Rao, C.S. Optimum combination of machining parameters during drilling of Aluminium 7075 alloys using Grey based Taguchi approach. J. Mech. Energy Eng. 2020, 4, 227-238. [CrossRef]

20. Kyratsis, P.; Markopoulos, A.P.; Efkolidis, N.; Maliagkas, V.; Kakoulis, K. Prediction of thrust force and cutting torque in drilling based on the response surface methodology. Machines 2018, 6, 24. [CrossRef]

21. Balaji, M.; Rao, K.V.; Rao, N.M.; Murthy, B. Optimization of drilling parameters for drilling of TI-6Al-4V based on surface roughness, flank wear and drill vibration. Measurement 2018, 114, 332-339. [CrossRef] 
22. Abdelhafeez, A.; Soo, S.; Aspinwall, D.; Dowson, A.; Arnold, D. Burr formation and hole quality when drilling titanium and aluminium alloys. Procedia CIRP 2015, 37, 230-235. [CrossRef]

23. Pena, B.; Aramendi, G.; Rivero, A.; de Lacalle, L.N.L. Monitoring of drilling for burr detection using spindle torque. Int. J. Mach. Tools Manuf. 2005, 45, 1614-1621. [CrossRef]

24. Rodríguez, A.; Calleja, A.; de Lacalle, L.L.; Pereira, O.; Rubio-Mateos, A.; Rodríguez, G. Drilling of CFRP-Ti6Al4V stacks using $\mathrm{CO}_{2}$-cryogenic cooling. J. Manuf. Process. 2021, 64, 58-66. [CrossRef]

25. Rivero, A.; de Lacalle, L.L.; Penalva, M.L. Tool wear detection in dry high-speed milling based upon the analysis of machine internal signals. Mechatronics 2008, 18, 627-633. [CrossRef]

26. Aamir, M.; Tolouei-Rad, M.; Giasin, K.; Vafadar, A. Feasibility of tool configuration and the effect of tool material, and tool geometry in multi-hole simultaneous drilling of Al2024. Int. J. Adv. Manuf. Technol. 2020, 111, 861-879. [CrossRef]

27. Sheikh-Ahmad, J.Y. Machining of Polymer Composites; Springer: Boston, MA, USA, 2009.

28. Aamir, M.; Tolouei-Rad, M.; Giasin, K. Multi-spindle drilling of Al2024 alloy and the effect of TiAlN and TiSiN-coated carbide drills for productivity improvement. Int. J. Adv. Manuf. Technol. 2021. ahead-of-print. [CrossRef]

29. Giasin, K.; Hodzic, A.; Phadnis, V.; Ayvar-Soberanis, S. Assessment of cutting forces and hole quality in drilling Al2024 aluminium alloy: Experimental and finite element study. Int. J. Adv. Manuf. Technol. 2016, 87, 2041-2061. [CrossRef]

30. Zhu, Z.; Guo, K.; Sun, J.; Li, J.; Liu, Y.; Zheng, Y.; Chen, L. Evaluation of novel tool geometries in dry drilling aluminium 2024-T351/titanium Ti6Al4V stack. J. Mater. Process. Technol. 2018, 259, 270-281. [CrossRef]

31. Hanif, M.I.; Aamir, M.; Ahmed, N.; Maqsood, S.; Muhammad, R.; Akhtar, R.; Hussain, I. Optimization of facing process by indigenously developed force dynamometer. Int. J. Adv. Manuf. Technol. 2019, 100, 1893-1905. [CrossRef]

32. Hanif, M.I.; Aamir, M.; Muhammad, R.; Ahmed, N.; Maqsood, S. Design and development of low cost compact force dynamometer for cutting forces measurements and process parameters optimization in turning applications. Int. J. Innov. Sci. 2015, 3, 306-3016.

33. Köklü, U. Influence of the process parameters and the mechanical properties of aluminum alloys on the burr height and the surface roughness in dry drilling. Mater. Tehnol. 2012, 46, 103-108.

34. Shetty, N.; Herbert, M.A.; Shetty, D.S.; Vijay, G.; Shetty, R.; Shivamurthy, B. Experimental investigation in drilling of carbon fiber reinforced polymer composite using HSS and solid carbide drills. Int. J. Curr. Eng. Technol. 2015, 5, 313-320.

35. Uddin, M.; Basak, A.; Pramanik, A.; Singh, S.; Krolczyk, G.M.; Prakash, C. Evaluating hole quality in drilling of Al 6061 alloys. Materials 2018, 11, 2443. [CrossRef]

36. Liu, K.; Li, J.; Sun, J.; Zhu, Z.; Meng, H. Investigation on chip morphology and properties in drilling aluminum and titanium stack with double cone drill. Int. J. Adv. Manuf. Technol. 2018, 94, 1947-1956. [CrossRef]

37. Yazman, Ş.; Gemı, L.; Uludă̆, M.; Akdemır, A.; Uyaner, M.; Dişpinar, D. Correlation Between Machinability and Chip Morphology of Austempered Ductile Iron. J. Test. Eval. 2017, 46, 1012-1021. [CrossRef]

38. Astakhov, V.P. Tribology of Metal Cutting; Elsevier Ltd.: Oxford, UK, 2006; Volume 52.

39. Administration, I.; Group, E.P.; Heginbotham, W.; Gogia, S. Metal cutting and the built-up nose. Proc. Inst. Mech. Eng. 1961, 175, 892-917.

40. Zitoune, R.; Krishnaraj, V.; Collombet, F. Study of drilling of composite material and aluminium stack. Compos. Struct. 2010, 92, 1246-1255. [CrossRef]

41. Pramanik, A.; Islam, M.; Basak, A.; Littlefair, G. Machining and tool wear mechanisms during machining titanium alloys. Adv. Mater. Res. 2013, 651, 338-343. [CrossRef] 